\title{
肺癌を含む重複癌23例の臨床的検討
}

\section{Clinical Study of 23 Cases of Double Primary Cancer \\ Involving Lung Cancer}

辰巳明利・北野司久・藤尾 彰・朝倉庄志・松井輝夫

\begin{abstract}
要旨：昭和 60 年 11 月までの 16 年半の閗に 23 例の肺癌を含む重複癌を経験し，そのうちの 20 例に 肺切除術を行った. 同時性13例, 異時性10例であって, 二つの癌の発見間隔が 1 年以内 のものが多かった. その男女比は, 男性19例, 女性 4 例と圧倒的に男性に多かった. 重 複臓器としては, 胃癌との重複が 7 例と最も多かったが, 肺多発癌 4 例や喉頭癌との重 複癌 3 例など気道に関連した重複癌も 7 例経験した. 肺癌の組織型では腺癌 11 例と最も 多かった。これら重複癌の予後は, 肺癌の予後に影響されるものが多く, 肺癌単独例の 子後と比較しても遜色のないように思われた。
\end{abstract}

〔肺癌 $27(2): 141 \sim 148,1987 〕$

Key words : Double primary cancer, Lung cancer, Operation.

\section{はじめに}

癌に対する診断および治療の進歩に従って, 病理学的検索もより厳密に行われるようになり, 近年種々の臓器原発の重複癌が報告されてい $ろ^{1), 2)}$. 肺癌を含む重複癌あるいは多発性原発性 肺癌についても既に数多くの臨床的検討がなさ れている3(13)が, これら重複癌症例について検 討することは, 癌発生に対する個体の素因, 同 一個体における他藏器原発の悪性腫瘍との臨床 的性格の比較, あるいは肺癌単独例との比較と いう面から興味深く, かつ臨床的意義があると 思われる。そこで, 昭和 60 年 11 月までに経験し た23例の肺癌を含む重複癌について臨床的検討 を試みた。

\section{対象症例}

対象は昭和 44 年 6 月より 60 年 11 月までの 16 年 半の間に天理よろづ相談所病院胸部外科で経験 した23例である (Table 1)。これらは, 臨床病理

天理よろづ相談所病院胸部外科
学的に重複癌と確定診断がついたものであり, 剖検によって初めて診断されたものは含めなか つた。なお, 重複癌の判定はWarren and Gates $^{14)}$ の判定基準に従った。二つの癌が同じ 組織型を示す場合, 一方が他方の転移であるか 否かが問題となるが, 分化度と発育様式などか ら病理組織学的検索を加えて判断した。すなわ ち，23例の中で同じ組織型を示したものは腺癌 6 例と扁平上皮癌 2 例であるが, これらは分化 度, 肺病巣と気管支上皮との連続性, 粘液産生 の有無などの点から検索すると重複癌と考えら れた。その他の症例は病理組織学的に明らかに 異った組織像を呈しており，重複癌と診断して 問題は無いと考えられた。

\section{結 果}

1. 頻度：昭和 44 年 6 月より 60 年 11 月までに当 科に入院した肺癌患者総数は607例で重複癌症 例23例はその3.79\%にあたる(Table 2).

2 . 年令：肺癌発症時の年令は $48 \sim 74$ 才, 平均 
Table 1. Clinical features of 23 cases of double primary cancer

\begin{tabular}{|c|c|c|c|c|c|c|c|c|c|c|c|}
\hline \multirow{2}{*}{ Case } & \multirow{2}{*}{ Age } & \multirow{2}{*}{ Sex } & \multicolumn{3}{|c|}{ First cancer } & \multicolumn{3}{|c|}{ Second cancer } & \multirow{2}{*}{ B. I. } & & Prognosis (a) \\
\hline & & & Organ & Histology & Therapy & Organ & Histology & Therapy & & \multicolumn{2}{|c|}{ Years/Months } \\
\hline 1 & 62 & $M$ & Larynx & Sq. & Rad. & Lung & Sq. & LPN & 1000 & 10 & $12 /$ (b) \\
\hline 2 & 51 & $F$ & Rectum & Ad. & Surgery & Lung & Ad. & LUL & 0 & $1 / 6$ & $1 / 4$ \\
\hline 3 & 67 & $M$ & Lung & S- & None & Stomach & Ad. & None & 675 & 10 & $/ 1$ \\
\hline 4 & 48 & $M$ & Lung & La. & Rad. & Lung & Ad. & $W / R$ & 1050 & $2 / 10$ & $7 / 7$ \\
\hline 5 & 59 & $M$ & Lung & Ad. & RUL & Lung & La. & RUL & 900 & 10 & $/ 3$ \\
\hline 6 & 67 & $M$ & Lung & Ad. & RLL & Stomach & Ad. & None & 250 & $/ 7$ & $/ 7$ \\
\hline 7 & 66 & $M$ & Lung & Sq. & LUL & Lung & Sq. & $W / R$ & 920 & $/ 11$ & $5 / 3$ \\
\hline 8 & 61 & $F$ & Lung & Sm. & Rad. & Uterus & Sq. & Rad. & 100 & $1 / 4$ & $4 / 10$ \\
\hline 9 & 68 & $M$ & Prostate & Ad. & Surgery & Lung & Sq. & Seg. & 470 & $/ 11$ & $1 / 9$ \\
\hline 10 & 62 & $F$ & Uterus & Sq. & Surgery & Lung & Sm. & Rad. & 600 & $4 / 8$ & $1 / 4$ ( ) \\
\hline 11 & 66 & $M$ & Lung & Sq. & LUL & Pancreas & Ad. & None & 920 & $5 / 8$ & $5 / 9$ \\
\hline 12 & 62 & $M$ & Esophagus & Ad. & Surgery & Lung & Ad. & RML, RLL & 1800 & 10 & 10 (d) \\
\hline 13 & 62 & $M$ & Rectum & Ad. & Surgery & Lung & Ad. & LUL, LLL & 400 & $6 /$ & $2 / 4$ \\
\hline 14 & 58 & $M$ & Lung & Sq. & RUL, RML & Prostate & Ad, & None & 600 & $1 / 1$ & $1 / 8$ \\
\hline 15 & 54 & $M$ & Prostate & Ad. & Surgery & Lung & Sq. & RLL & 800 & $4 / 4$ & $4 / 4 *$ \\
\hline 16 & 57 & $M$ & Lung & La. & RUL & Stomach & Ad. & Surgery & 800 & $/ 1$ & $3 / 11 *$ \\
\hline 17 & 69 & $M$ & Stomach & Ad. & Surgery & Lung & Sq. & RML, RLL & 1500 & 10 & $3 / 5 *$ \\
\hline 18 & 51 & $M$ & Lung & Ad. & $W / R$ & Lung & $\mathrm{Sm}$ & $W / R$ & 400 & $2 / 6$ & $3 / 4 *$ \\
\hline 19 & 74 & $M$ & Larynx & Sq. & Surgery & Lung & Ad. & LUL & 550 & $12 / 5$ & $1 / 1 *$ \\
\hline 20 & 66 & $F$ & Stomach & Ad. & Surgery & Lung & Ad. & LUL & 0 & 10 & 19 \\
\hline 21 & 72 & $M$ & Stomach & Ad. & Surgery & Lung & Ad. & RLL & 1000 & 10 & $/ 7 *$ \\
\hline 22 & 70 & $M$ & Larynx & Sq. & Rad. & Lung & Ad. & RUL & 600 & 10 & 10 (e) \\
\hline 23 & 73 & $M$ & Lung & Sq. & LLL & Stomach & Ad. & Surgery & 1500 & 10 & $/ 5 *$ \\
\hline
\end{tabular}

Legend : M;Male, F;Female, Sq.;Squamous cell carcinoma. Ad.;Adenocarcinoma, La.;Large cell ca.. Sm;Small cell ca.. LPN; left pneumonectomy, LUL; left upper lobectomy, LLL;left lower lobectomy, RUL; right upper lobectomy, RML; right middle lobectomy, RLL; right lower lobectomy, Seg; Segmentectomy. W/R; Wedge resection, Rad.; Radiation therapy.

B. I.; Brinkman index, *; alive and well, (a); Survival from onset of lung cancer, (b):Died from pneumonia. (C): Follow up loss.

(d): Operation death, (e); Death due to arrhythmia

Table 2. Double primary cancer

\begin{tabular}{|c|c|}
\hline & $\begin{array}{l}\text { No. of } \\
\text { cases }\end{array}$ \\
\hline Incidence : Cases per & $23 / 607$ \\
\hline total No. of lung cancers & $3.79 \%$ \\
\hline \multicolumn{2}{|l|}{ Sex } \\
\hline Male & 19 \\
\hline Female & 4 \\
\hline Total & 23 \\
\hline Synchronous & 13 \\
\hline Identical histology & 6 \\
\hline Different histology & 7 \\
\hline Metachronous & 10 \\
\hline Identical histology & 2 \\
\hline Different histology & 8 \\
\hline Total & 23 \\
\hline
\end{tabular}

\section{8オであった.}

3. 性別：男性19例，女性 4 例と圧倒的に男性 が多かった (Table 2).

4. 哭煙歴：Brinkman index (B.I.) 400以上の
Table 3. Counterpart organs and histological typing

\begin{tabular}{|c|c|c|c|c|c|}
\hline \multirow{2}{*}{$\begin{array}{c}\text { Counterpart } \\
\text { organs }\end{array}$} & \multicolumn{4}{|c|}{ L'ung cancer } & \multirow{2}{*}{ No. of patients } \\
\hline & Ad. & Sq. & La. & $\mathrm{Sm}$. & \\
\hline Stomach (Ad.) & 3 & 3 & 1 & & 7 \\
\hline Lung & & & & & \\
\hline (Ad.) & & & 2 & 1 & $3^{*}$ \\
\hline (Sq.) & & 1 & & & 1 \\
\hline Prostate (Ad.) & & 3 & & & 3 \\
\hline Larynx (Sq.) & 2 & 1 & & & 3 \\
\hline Rectum (Ad.) & 2 & & & & 2 \\
\hline Uterus (Sq.) & & & & 2 & 2 \\
\hline Esophagus (Ad.) & 1 & & & & 1 \\
\hline Pancreas (Ad.) & & 1 & & & 1 \\
\hline Total & $8\left(+3^{*}\right)$ & 9 & 3 & 3 & 23 \\
\hline
\end{tabular}

Legend: Ad.;Adenocarcinoma, Sq.;Squamous cell carcinoma

La.; Large cell carcinoma. Sm.;Small cell carcinoma

肺癌症例が19例で，これらの組織型別分類では 扁平上皮癌 9 例, 腺癌 8 例, 大細胞癌 3 例, 小 細胞癌 2 例の順であった. また，B.I. 1,000以上 のものは 6 例であった。

5 ．家族歴：再親または同胞に悪性腫瘍の既往 のあるものは 9 例 (39.1\%)であった。

6. 肺癌の治療前臨床分類 (UICC, TNM) : 23 
Table 4. Operative procedures and curability for lung cancer versus survival in 20 patients

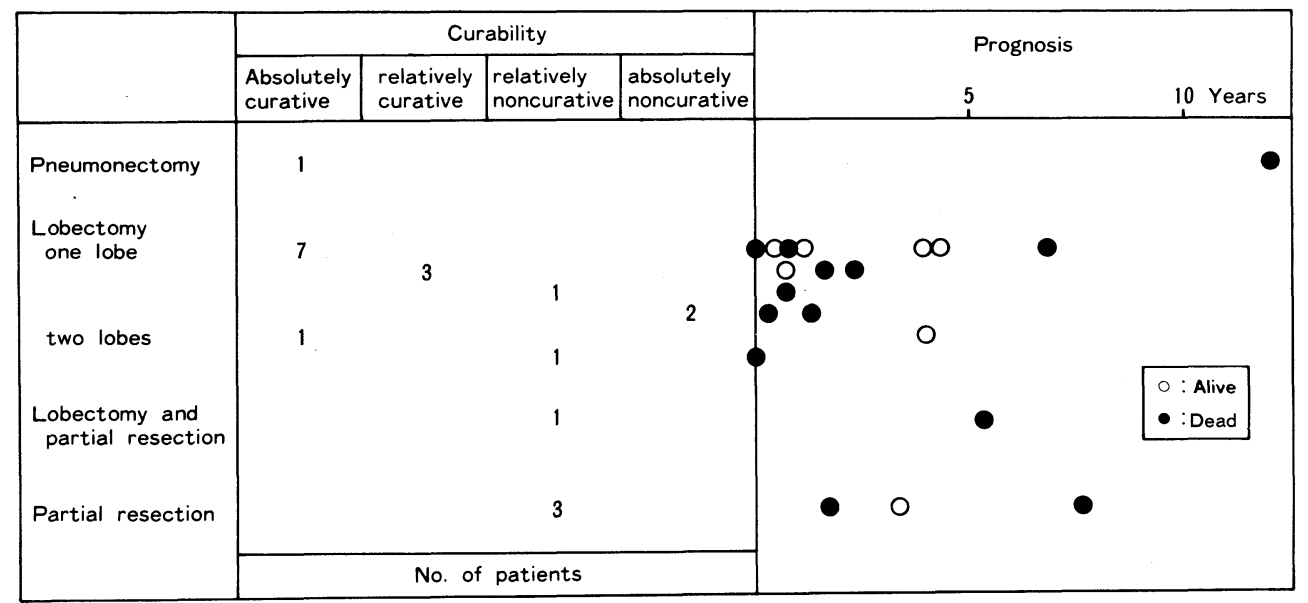

例の内訳はStage I 9 例, Stage II 2 例, Stage III 10例, StageIV 2例であった.

7. 重複藏器 : 重複臟器別では胃 7 例, 肺 4 例, 前立腺 3 例, 喉頭 3 例, 直腸 2 例, 子宮 2 例, 食道 1 例, 膵 1 例の順であった (Table 3$)$. 本邦 では胃癌の発生頻度が高いことからみて, 胃癌 との重複が多いのは当然と思われるが, 喉頭 癌一肺癌の組合わせと肺の多発癌を合せた気道 に関連した重複癌が 7 例で, これは消化器系の 11例に次いで多かった。また，この 7 例全例に 喫煙歴があって, タバコ発癌の関連性が示唆さ れた。

8. 肺癌の組織型：組織型別の分類では腺癌 11 例, 扁平上皮癌 9 例, 大細胞癌 3 例, 小細胞癌 3 例であった(肺多発癌の重複も含む, Table 3).

9. 発見間隔と第 2 癌の発見動機：二つの癌の 発見時期についてみると, 第 1 癌治療前の検査 中に偶然発見されたものが 9 例, 第 1 癌治療開 始後経過観察中の 1 年以内に偶然あるいは症状 を訴之て第 2 癌が発見されたものが 4 例あった. すなわち，二つの癌が 1 年以内の間隔で発見さ れた，いわゆる同時性 (synchronous)のものは 13例であった (Table 2).これに対し， 1 年以上 の間隔があいた異時性 (metachronous)の重複 癌は 10 例で, そのうち 7 例に肺癌が第 2 癌とし て発生している。異時性第 2 癌の発見動機を検
討すると, 症状が発現して発見されたものが 6 例 (肺癌 3 例, 膵癌 1 例, 前立腺癌 1 例, 子宮癌 1 例) と最も多く, 次に第 1 癌が肺癌でその経過 観察中にあらたに発見された肺癌が 2 例，検診 で発見された肺癌が 1 例，そして，他疾患の精 查中偶然発見された肺癌が 1 例であった。第 1 癌, 第 2 癌の発見間隔の最長は 12 年 5 か月に及 んでいる。統計学的にみても, 担癌患者の第 2 癌に罹患する頻度は健康人より高いことが示さ れており ${ }^{15), 16)}$ ，第 1 癌治療後における重複癌の 発生をも考慮にいれて経過観察する必要がある。 10. 第 1 癌に対する治療：第 1 癌に対して行わ れた主な治療法は, 手術のみ行われたもの12例, 手術 + 化学療法 4 例, 手術 + 放射線療法 1 例, 手術 + 化学療法 +放射線療法 1 例, 化学療法十 放射線療法 2 例, 放射線療法のみ 2 例で, 残り 1 例は全身状態不良のため治療ができなかった。 Table 1には主な治療法を示した。

11. 肺癌に対する治療：肺剔除術 1 例, 肺葉切 除術のみ15例, 肺葉切除術を行い11か月後に新 たに原発性肺癌を対側に生じたために肺部分切 除術を行ったもの 1 例(症例 7 ), 肺区域切除術 または肺部分切除術を行ったもの 3 例(症例 4 , 9 ，18）で，合計20例に外科療法が行われた (Table 4). 小細胞癌でStageIII, IV の 2 症例 (症 例 8,10$)$ に対しては放射線療法および化学療法 を併用した。 
12. 予後：23例の予後をTable 1およびFig. 1 に示す. 死亡 15 例のうち, 肺癌が直接死因とな ったものは男性 6 例, 女性 3 例のあわせて 9 例 であった. 残り 6 例の死因は, 肺癌以外の癌死 3 例 (症例 $6,11,14$ ), 重複癌と無関係な他病 死 2 例 (症例 1,22 ), それに術死 1 例 (症例12) であった。肺癌に対して外科療法を行い得た 20 例について，その術式と予後の関係をみると， 肺剔除術と肺葉切除術があわせて17例と多く, 絶対的治瘾切除も 9 例あるが，その予後をみる と他藏器癌との関係もあって必ずしも, 肺部分 切除術よりも良好とは言いきれない(Table 4). 術式が肺部分切除術となったのは, 第 1 癌の根 治性に問題が残る症例の第 2 癌, あるいは手術 後も発癌の可能性が高い職業性肺癌の症例であ った。また，全例における肺癌発症時期からの 経過は最長144か月で, Kaplan-Meier法で求め た 1 年生存率 $73.1 \%, 3$ 年生存率 $50.9 \%$ であっ た.

\section{考 察}

重複癌の定義は広義ではmultiple cancerの ことで, 同系統あるいは異種系統の二つ以上の 臓器にそれぞれ独立して腫瘍が発生した場合 (狭義の重複癌) と, 同一臟器に腫瘍が多発した 場合 (多発癌) の両者の意味で使用される。重複 癌 (multiple primary malignant tumor)の定義

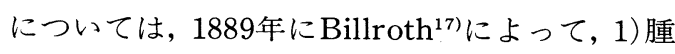
瘍は互いに異った組織像を呈し，2) それぞれ組 織発生学的に母組織と関連を有し，3）それぞれ 固有の転移巣を有するもの，と三つの条件を挙 げている。しかし，この定義ではあまりにも厳 し過ぎるため, 現在ではWarren \& Gates ${ }^{14)} の$ 定義すなわち，1）それぞれの腫瘍は一定の悪性 度を呈し，2）互いに離れた部位に存在し，3）一 方の腫瘍が他方の転移でない，という条件が一 般に広く用いられている。赤崎ら ${ }^{18)}$ は同一藏器 においても二つ以上の癌が独立して発生した場 合にも重複癌として取り扱っており，最近では 重複癌は多発癌も含めて多重複癌として用いら れるようになってきた。

重複癌の定義はこのように未だ混乱している
Fig. 1. Survival rates of patients with double cancer

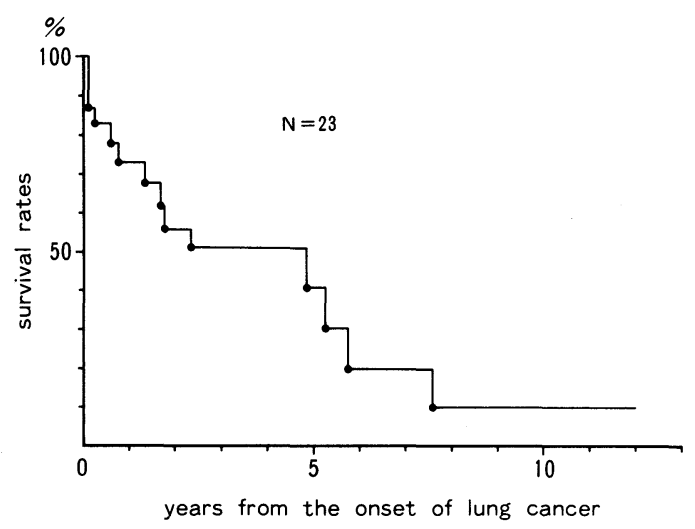

が, 臨床の立場から大切なことは, 原発性か転 移性かということであり，それが治療方針を大 きく左右するからである。本稿では肺癌と他臓 器癌の組合せと, 肺内多発癌も含めて肺癌を含 む重複癌として取り扱った。

重複癌の発生頻度が近年増加傾向にあること は『日本病理剖検輯報』からも明らかである。 栗山ら ${ }^{199}$ にると, 全肺悪性腫瘍に占める肺癌 を含む重複癌は, 昭和 50 年の $5.41 \%$ から昭和 55 年には $9.63 \%$ と増加傾向を示している。近年, 胃癌を追い越して癌死のトップを占めた肺癌は 注目され，その診断技術の進歩や住民検診の徹 底などによる早期発見に力が注がれている。し かしその予後は極めて悪く, 運よく切除できた 症例でも 5 年生存率は $40 \%$ に満たない現状であ る. 手術を受けた症例で, 術後 3 年を生存し得 た症例でも, 剖検時には $61.5 \%$ と高率に転移巣 が発見されている ${ }^{19)}$.この事実は, 肺癌の転移の おこし易さと同時に肺癌治療の困難性を示すも のである。

肺癌は大別して, 扁平上皮癌, 腺癌, 大細胞 癌, 小細胞癌, その他に分類され, この病理分 類によってある程度治療方針が臨床的に決定さ れている.しかし, 周知のように, 実地臨床上 これらの分類に明確に分けられるのではなく, たとえば, 腺癌と診断されても, 一部に扁平上 皮癌や大細胞癌の組織像が見られることは稀で はない.このように多彩な組織像を呈すること 
が肺癌の特徵と言われている。そしてこのこと が肺癌を含む重複癌の診断を困難なものにして いる。たとえば, 肺内多発癌で互いに組織型が 明らかに異る場合には肺一肺の重複癌と診断し てさしつかえないが, 組織型が同じである場合 には肺内転移との鑑別が必要となる20).また, 肺 は大循環系諸藏器癌の転移し易い第 1 標的藏器 でありここことも肺癌を含む重複癌の診断を 困難にしている.Cahanら ${ }^{21)}$ は乳癌と肺癌の合 併例において, 同じ腺癌であっても, 肺癌病巣 が接近する気管支上皮と直接に連続している場 合や，正常肺組織付近にcarcinoma in situが見 られる場合には, 原発性肺癌と診断してさしつ かえないとしている。実地臨床上, 肺病巣が単 発で他藏器癌と同じ組織型の場合, あるいは肺 癌手術後に肺に新しい病巣を生じた場合にそ れが原発性か転移性かと診断に迷うことが多い. しかし, 転移性肺癌に対しても積極的に切除術 を行っている現在, いたずらに迷うことなく早 期に外科治療を行うべきである．23例中20例に 対して外科療法を施行できたが，肺転移または 再発を疑って切除したところ重複癌であったも のが 7 例もあった。これらの症例は, 積極的な 切除によって確定診断ができたわけで，消極策 をとった際には重複癌を見逃す危険がある。こ のように, 癌の術後経過観察にあたっては, 第 2 癌発生の可能性も考慮に入れる必要がある.

23 例の重複癌が肺癌全症例に占める頻度は $3.8 \%$ で他の報告と大差は無かった ${ }^{8), 10), 22)}$.

年令は肺癌発症時の平均が 62.8 オで, 当科に おける肺癌単独手術例のそれと比較して差は認 めなかった。

性別では19対 4 と圧倒的に男性が多かったが, これは元来肺癌が男性に多い上に， 3 例が前立 腺との組合せであること, 乳癌および甲状腺癌 症例が 1 例も無かったことなどに起因するもの と思われる。

契煙歴では, B.I. 400以上が19例で全体の82.6 \%を占め，また，喉頭と肺を合せた気道関連の 重複癌が 7 例と多く, この事実は煙草のcar: cinogenの関与がうかがわれた.

家族歴については，23例中 9 例 (39.1\%)に両
親または同胞に悪性腫瘍の既往があった。この うち, 家族歴と同じ悪性腫瘍を有したのは症例 17 胃癌一肺癌の 1 例のみであるが, 同胞ふた りがそれぞれ胃癌, 肺癌で死亡しており興味深 い,また, 症例20は両親がそれぞれ喉頭癌, 子 宮癌で死亡し, 伯母も胃癌死であって濃厚な家 族性因子を示唆した。癌を多発する家系におい て重複癌が多くなることは他の報告者たち ${ }^{23), 24)}$ も述べており, 家族性因子の存在を強くうかが わせた。

重複臟器は胃が 7 例と最も多く, 4 例で第 2 癌として発見されているが， 7 例とも肺癌との 発見間隔は 7 か月以内の同時性重複癌で, 入院 時検查でほぼ同時に両者が発見された症例もあ つた.

1 年以内の間隔で二つの癌が発見されたのは 13 例で, 3 年以上の間隔があいた症例は 5 例の みであった。これら発生間隔の長い症例は, 喉 頭癌, 直腸癌, 前立腺癌, 子宮癌という比較的 予後良好な癌が第 1 癌として存在したか, また は, 第 2 癌として膵癌が発生したものであった. 肺癌発症時からみた予後は, 1 年生存率 $73.1 \%$, 3 年生存率 $50.9 \%$ であって, 肺癌単独例の成績 と比較しても遜色のないように思われた。これ は肺癌の生物学的悪性度を示すもので, 肺癌の 治療成績の向上がこれら重複癌の予後向上につ ながると思われる。

以上当科で経験した23例の肺癌を含む重複癌 について検討したが, その結果から, 肺癌の外 科療法にあたっては, 根治性を確立するために 十分な切除範囲をとることは当然であるが, 残 存肺機能が術後のquality of lifeに反映するの で, 症例によっては肺部分切除術, 肺区域切除 術などのlimited operationも考慮して肺機能温 存に努め, また, 術後の経過観察にあたっては, 他臓器癌を含む第 2 癌発生の可能性も考慮する 必要があると思われた。 Christensenら ${ }^{25) ~ 27) も ， ~}$ 部分切除を積極的にとり入れることによって長 期生存が得られるとしている。そして, 肺以外 の臓器に腫瘍があって肺に孤立性陰影が出現し た場合でも，直ちに肺転移と即断することなく， 独立した二つの腫瘍である可能性もあることを 
考慮に入れて積極的診断とその治療を慎重に進 める必要があると思われた。

\section{まとめ}

当科で経験した肺癌を含む重複癌について臨 床的検討を行い次の結果を得た。

1. 肺癌を含む重複癌症例は 23 例で, 全肺癌症 例の $3.8 \%$ 占めた。このうち, 20 例に肺癌に対 する外科治療を行うことができた。

2 . 肺癌発見時の年令は, $48 \sim 74$ 才で平均 62.8 オであった。

3. 男女比では 19 対 4 と圧倒的に男性に多く,
胃癌との組合せが最も多かった。そして，前立 腺癌, 喉頭癌がこれに次いで上位を占めた。

4. 肺癌の組織型は腺癌 11 例, 扁平上皮癌 9 例, 大細胞癌，小細胞癌がそれぞれ 3 例であった。

5 . 二つの癌の発見間隔が 1 年未満の同時性重 複癌は 13 例で, 3 年以上の症例は 5 例であり, 発生間隔の長い症例は比較的予後良好な癌を第 1 癌とする傾向にあった。

6. 重複癌の予後は肺癌の予後に影響されてい るものが多く，肺癌の治療成績をあげることが これら重複癌の予後の向上につながると思われ た.

\section{文 献}

1）谷村繁雄, 米山武志, 末多恵一, 他：重複癌の 診断, 治療及び予後。日癌治, $17 ： 2001-2007$, 1982.

2）桧垣健二, 西山宜孝, 吉井淳哲, 他：当院にお ける重複癌の統計的考察. 癌の臨床, $29: 381-$ 388, 1983.

3) 渡辺洋宇, 岩喬, 山田哲司, 他: 肺癌と他 臟器重複癌症例の検討. 日胸, $37 ： 623-630$, 1978.

4）川口忠彦, 福島松郎, 鯉江久昭：肺癌と他臟器 重複癌の検討。外科診療, $23: 355-358,1981$.

5）藤井俊宏, 西亀正之, 奥道恒夫, 他：肺と他臓 器との重複癌症例の検討。日胸, $40: 744-749$, 1981.

6）富田正雄, 綾部公懿, 川原克信, 他 : 肺癌との 重複癌症例の検討。外科, $45: 1435-1438$, 1983.

7）有村利光, 三谷惟章, 下高原哲朗, 他：肺と胃 の同時性重複癌の 3 手術例と本邦報告例の検 討。癌の臨床, 30：283-291，1984。

8) Nishiki, M., Kataoka, T., Okumichi, T., et al. : A study of multiple primary malignant neoplasms associated with lung cancer. Hiroshima J. of medical sciences, $33: 447-453$, 1984.

9）小川純一, 井上宏司, 小出司郎策, 他：肺癌を 含屯重複癌症例の臨床的検討. 肺癌, $25: 649$ $655,1985$.

10）雨宮隆太, 早田義博, 平良 修, 他：肺癌と他
藏器重複癌. 最新医学, $40: 1658-1668,1985$.

11）谷村繁雄, 梶田正文, 土屋了介, 他：多発性原 発性肺癌の診断・治療および予後。肺癌, 22 : 45-52, 1982.

12）東口高志，金森由郎，谷一浩，他：同時に多 発した原発性肺癌の 1 切除例. 癌の臨床, 29 ： 1007-1011， 1983.

13）米山武志, 小池 薫, 江口研二, 他：肺癌のbed side epidemiology -臨床的重複癌の分析一. 日 胸, 43：733-741， 1984.

14) Warren, S., Gates, O., : Multiple primary malignant tumors. A survey of the literature and a statistical study. Am. J. Cancer, 16 : 1358-1414, 1932.

15) Campbell, L.V., Watne, A.L. : Multiple primary malignant neoplasms. Arch. Surg., 99: 401-405, 1969.

16) Berg, J.W., Schottenfeld, D. : Multiple primary cancers at Memorial Hospital 19491962. Cancer, $40: 1801-1805,1977$.

17) Billroth, T.: Die allegemeine chirurgische Pathologie und Therapie in 51 Vorlesungen, Ein Handbuch für Studierende und Ärzte. 14 Aufl. Berlin, Germany, p.908, 1889-cited from 14).

18）赤崎兼義, 若狭治毅, 石館卓三：原発性重複癌 について. 日本臨床，19：1543-1551，1961.

19）栗山喬之, 鈴木公典, 椙田 隆, 他：肺癌との 重複癌一特に術後生存期間との関連から一. 呼 
吸, $3: 951-958,1984$.

20) Martini, N., Melamed, M.R. : Multiple primary lung cancers. J. Thorac. Cardiovasc. Surg., $70: 606-612,1975$.

21) Cahan, W.G., Castro, El B., Huvos, A.G. : Primary breast and lung carcinoma in the same patient. J. Thorac. Cardiovasc. Surg., $68: 546-555,1974$,

22）森田豊彦：一般剖検例における重複癌と肺癌 を含むものの検討一肺癌を含む重複癌の 22 剖 検例を中心にして一. 癌の臨床, $23 ： 1033-$ 1042, 1977.

23) Lynch, H.T., Krush, A.J. : Differential diagnosis of the cancer family syndrome. Surg. Gynecol. Obstet,, 136 : 221-224, 1973.
24）阿南敏郎, 宮部雅次, 辻 秀男：当科における 重複癌31例の検討. 外科診療, $22: 697-701$, 1980.

25) Struve-Christensen, E. : Diagnosis and treatment of bilateral primary bronchogenic carcinoma. J. Thorac. Cardiovasc. Surg., 61 : 501-513, 1971.

26) Jensik, R.J., Faber, L.P., Milloy, F.J., et al. : Segmental resection for lung cancer. A fifteen-year experience. J. Thorac. Cardiovasc. Surg., $66: 563-572,1973$.

27) Shields, T.W., Higgins, G.A. : Minimal pulmonary resection. In treatment of carcinoma of the lung. Arch. Surg., $108: 420-422,1974$. 


\title{
Clinical Study of 23 Cases of Double Primary Cancer Involving Lung Cancer
}

\author{
Akitoshi Tatsumi, Morihisa Kitano, Akira Fujio, \\ Shoji Asakura and Teruo Matsui \\ Department of Thoracic Surgery \\ Tenri Hospital, Tenri, Nara
}

Twenty-three cases of double primary cancer involving lung cancer were experienced from June, 1969, to November, 1985.

The incidence was 3.8 per cent of all hospitalized cases of primary lung cancer. The patients included 19 males and 4 females, a ratio of 5 to 1 . Their ages at the time of detection of the lung cancer ranged from 48 to 74 years with an average age of 62.8 years. Thirteen out of 23 cases of double cancer appeared synchronously. Of 20 patients who had pulmonary excision, 16 had lobectomies, one had a pneumonectomy and 3 had segmentectomies or wedge resections. The counterpart organs involved were the stomach in 7 cases, prostate and larynx in 3 cases each, rectum and uterus in 2 cases each and esophagus and pancreas in 1 case each. There were four multiple lung cancers. In respect to the histological type of lung cancer, 11 were adenocarcinoma, 9 were squamous cell carcinoma, 3 were small cell carcinoma and 3 were large cell carcinoma.

The incidence of double primary cancer tends to increase in time, and the prognosis of double primary cancer involving lung cancer will depend on the clinical course of the lung cancer. Nevertheless, limited resection for lung cancer can occasionally be recommended to conserve pulmonary function as much as possible. The possibility of a second primary cancer should be considered carefully whenever a solitary shadow appears on the chest roentgenogram of a patient who has been treated for another cancer before. 